\title{
Bispecific antibodies and their applications
}

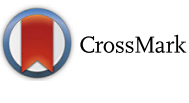

\author{
Gaowei Fan ${ }^{1,2}$, Zujian Wang ${ }^{3}$, Mingju Hao ${ }^{1,2}$ and Jinming $\mathrm{Li}^{1,2^{*}}$
}

\begin{abstract}
Bispecific antibodies (BsAbs) recognize two different epitopes. This dual specificity opens up a wide range of applications, including redirecting T cells to tumor cells, blocking two different signaling pathways simultaneously, dual targeting of different disease mediators, and delivering payloads to targeted sites. The approval of catumaxomab (anti-EpCAM and anti-CD3) and blinatumomab (anti-CD19 and anti-CD3) has become a major milestone in the development of bsAbs. Currently, more than 60 different bsAb formats exist, some of them making their way into the clinical pipeline. This review summarizes diverse formats of bsAbs and their clinical applications and sheds light on strategies to optimize the design of bsAbs.
\end{abstract}

Keywords: Bispecific antibody, BiTE, Cancer, Formats, Catumaxomab, Diagnosis

\section{Background}

Currently, 44 monoclonal antibody (mAb)-based products are marketed, which generated approximately $\$ 75$ billion USD in total worldwide sales in 2013 [1]. Therapeutic antibodies have become a mainstay of therapeutic options for patients with cancer and autoimmune, inflammatory, and various other diseases [2, 3]. However, $\mathrm{mAbs}$ have several limitations. Patients receiving $\mathrm{mAb}$ therapy may develop drug resistance or fail to respond to treatment [4]. Cancer and other diseases are multifactorial, with many signaling pathways implicated in pathogenesis. Single-target immunotherapy does not seem to destroy cancer cells sufficiently. Bispecific antibodies (BsAbs) have been posited as potential cancer therapeutic agents for decades but have only recently begun to bear fruit. BsAbs show several advantages [5]: (1) bsAbs can redirect specific immune cells to the tumor cells to enhance tumor killing, (2) bsAbs will enable the simultaneous blocking of two different mediators/ pathways that exert unique or overlapping functions in pathogenesis, and (3) bsAbs can potentially increase binding specificity by interacting with two different cell-surface antigens instead of one.

The development of bsAbs has long been hampered by manufacturing problems such as product instability,

\footnotetext{
*Correspondence: jmli@nccl.org.cn

'National Center for Clinical Laboratories, Beijing Hospital, No 1 Dahua Road, Dongdan, Beijing 100730, China

${ }^{2}$ Graduate School, Peking Union Medical College, Chinese Academy of

Medical Sciences, Beijing 100730, China

Full list of author information is available at the end of the article
}

low expression yields, and immunogenicity [6]. Newer formats of bsAbs that are more stable, easier to produce, and less immunogenic have been made available. Currently, over 30 bsAbs are in clinical development, with two of the front-runners approved for the market (Table 1).

BsAbs are primarily produced by three methods [7]: (1) quadroma technology based on the somatic fusion of two different hybridoma cell lines, (2) chemical conjugation, which involves chemical cross-linkers, and (3) genetic approaches utilizing recombinant DNA technology. These technologies have revolutionized the development of bsAbs, and a large variety of formats have been generated to cater to particular applications, some of which are discussed in this review.

\section{BsAb formats}

BsAbs can be roughly divided into two categories: immunoglobulin G (IgG)-like molecules and non-IgG-like molecules (Fig.1). IgG-like bsAbs retain Fc-mediated effector functions such as antibody-dependent cellmediated cytotoxicity (ADCC), complement-dependent cytotoxicity (CDC), and antibody-dependent cellular phagocytosis (ADCP) [6]. The Fc region of bsAbs facilitates purification and improves solubility and stability. BsAbs in IgG-like formats usually have longer serum half-lives owing to their larger size and FcRn-mediated recycling [8]. Non-IgG-like bsAbs are smaller in size, leading to enhanced tissue penetration [8]. 
Table 1 Bispecific antibodies in clinical trials. Information from ClinicalTrials.gov (https://clinicaltrials.gov)

\begin{tabular}{|c|c|c|c|c|c|c|}
\hline BsAb & Sponsor & Formats & Targets & Biological function & Clinical trial $\times$ identifier & Diseases \\
\hline \multirow[t]{5}{*}{ Catumaxomab } & Neovii Biotech & Triomab & EpCAM $\times$ CD3 & $\begin{array}{l}\text { T cell recruitment, Fc-mediated } \\
\text { effector function }\end{array}$ & Approved in EU & $\begin{array}{l}\text { EpCAM-positive tumor, malignant } \\
\text { ascites }\end{array}$ \\
\hline & AGO Study Group & & & & $\begin{array}{l}\text { Completed phase lla, } \\
\text { NCT00189345 }\end{array}$ & $\begin{array}{l}\text { Platinum refractory epithelial } \\
\text { ovarian cancer }\end{array}$ \\
\hline & AlO-Studien-gGmbH & & & & Phase II, NCT01504256 & Gastric adenocarcinomas \\
\hline & $\begin{array}{l}\text { Grupo Español de Investigación } \\
\text { en Cáncer de Ovario }\end{array}$ & & & & Phase II, NCT01246440 & Ovarian cancer \\
\hline & Gustave Roussy & & & & Phase IINCT01784900 & Gastric peritoneal carcinomatosis \\
\hline Ertumaxomab & Krankenhaus Nordwest & Triomab & HER2 $\times$ CD3 & $\begin{array}{l}\text { T cell recruitment, Fc-mediated } \\
\text { effector function }\end{array}$ & Phase I/II, NCT01569412 & $\begin{array}{l}\text { Her2/Neu-positive advanced solid } \\
\text { tumors }\end{array}$ \\
\hline FBTA05 & Technische Universität München & TrioMab & $\mathrm{CD} 20 \times \mathrm{CD} 3$ & T cell recruitment & Phase I/II,NCT01138579 & Leukemia \\
\hline \multirow[t]{7}{*}{ Blinatumomab } & Amgen Research (Munich) GmbH & BiTE & $\mathrm{CD} 3 \times \mathrm{CD} 19$ & T cell recruitment & Approved in USA & ALL \\
\hline & Amgen Research (Munich) GmbH & & & & Phase I, NCT00274742 & Relapsed NHL \\
\hline & Amgen Research (Munich) GmbH & & & & Phase II, NCT01207388 & B cell ALL \\
\hline & Amgen Research (Munich) GmbH & & & & Phase II, NCT01209286 & Relapsed/refractory ALL \\
\hline & National Cancer Institute & & & & Phase I, NCT02568553 & $\mathrm{NHL}$ \\
\hline & National Cancer Institute & & & & Phase II, NCT02143414 & $\begin{array}{l}\text { Adult B-ALL with } \mathrm{t}(9 ; 22)(\mathrm{q} 34 ; \mathrm{q} 11.2) \text {; } \\
\text { BCR-ABL1; untreated adult ALL }\end{array}$ \\
\hline & National Cancer Institute & & & & Phase III, NCT02003222 & $B C R-A B L$-negative $B$ lineage $A L L$ \\
\hline $\begin{array}{l}\text { Solitomab (MT110, } \\
\text { AMG 110) }\end{array}$ & Amgen Research (Munich) GmbH & BiTE & CD3 $\times$ EpCAM & $\mathrm{T}$ cell recruitment & $\begin{array}{l}\text { Completed phase I, } \\
\text { NCT00635596 }\end{array}$ & Solid tumors \\
\hline AMG 330 & Amgen & BiTE & $\mathrm{CD} 33 \times \mathrm{CD} 3$ & $\mathrm{~T}$ cell recruitment & Phase I, NCT02520427 & Relapsed/refractory AML \\
\hline MT112 (BAY2010112) & Bayer & BiTE & $\mathrm{PSMA} \times \mathrm{CD} 3$ & T cell recruitment & Phase I, NCT01723475 & Prostatic neoplasms \\
\hline MT111 (MEDI-565) & Medlmmune LLC & BiTE & $\mathrm{CEA} \times \mathrm{CD} 3$ & T cell recruitment & $\begin{array}{l}\text { Completed phase I, } \\
\text { NCT01284231 }\end{array}$ & Gastrointestinal adenocarcinomas \\
\hline BAY2010112 & Bayer & BiTE & CD3 $\times$ PSMA & T cell recruitment & Phase I, NCT01723475 & Prostatic neoplasms \\
\hline MEDI-565 & Medlmmune LLC & BiTE & $\mathrm{CEA} \times \mathrm{CD} 3$ & T cell recruitment & $\begin{array}{l}\text { Completed phase I, } \\
\text { NCT01284231 }\end{array}$ & Gastrointestinal adenocarcinomas \\
\hline MDX447 & $\begin{array}{l}\text { Dartmouth-Hitchcock Medical } \\
\text { Center }\end{array}$ & $\begin{array}{l}2(\text { Fab') was } \\
\text { crosslinked }\end{array}$ & CD64 × EGFR & Active monocytes to kill tumor & $\begin{array}{l}\text { Completed phase I, } \\
\text { NCT00005813 }\end{array}$ & $\begin{array}{l}\text { Brain and central nervous system } \\
\text { rumors }\end{array}$ \\
\hline \multirow[t]{4}{*}{ TF2 } & $\begin{array}{l}\text { Garden State Cancer Center at the } \\
\text { Center for Molecular Medicine and } \\
\text { Immunology }\end{array}$ & Dock and lock & $\mathrm{CEA} \times \mathrm{HSG}$ & $\begin{array}{l}\text { Enzyme-linked immunosorbent } \\
\text { assay }\end{array}$ & Phase I, NCT00895323 & Colorectal cancer \\
\hline & Centre René Gauducheau & & & Radioimmunotherapy & Phase I/II, NCT01221675 & Small cell lung cancer \\
\hline & Nantes University Hospital & & & Immuno-PET & Phase I/II, NCT01730638 & $\begin{array}{l}\text { Recurrences of medullary thyroid } \\
\text { carcinoma }\end{array}$ \\
\hline & Nantes University Hospital & & & Immuno-PET & Phase I/II, NCT01730612 & \\
\hline
\end{tabular}


Table 1 Bispecific antibodies in clinical trials. Information from ClinicalTrials.gov (https://clinicaltrials.gov) (Continued)

\begin{tabular}{|c|c|c|c|c|c|c|}
\hline & & & & & & $\begin{array}{l}\text { HER2 negative breast carcinoma } \\
\text { expressing CEA }\end{array}$ \\
\hline & Radboud University & & & Radioimmunotherapy & $\begin{array}{l}\text { Completed phase I, } \\
\text { NCT00860860 }\end{array}$ & Colorectal neoplasms \\
\hline rM28 & University Hospital Tuebingen & Tandem scFv & $\begin{array}{l}\text { CD28 } \times \text { HMV- } \\
\text { MAA }\end{array}$ & $\begin{array}{l}\text { Retargeting autologous } \\
\text { lymphocytes to tumor }\end{array}$ & Phase I/II, NCT00204594 & Malignant melanoma \\
\hline HER2Bi-aATC & $\begin{array}{l}\text { Barbara Ann Karmanos Cancer } \\
\text { Institute }\end{array}$ & $\begin{array}{l}\text { T cells preloaded with } \\
\text { bsAbs }\end{array}$ & $\mathrm{CD} 3 \times \mathrm{HER} 2$ & Activated T cells & Phase I, NCT02470559 & $\begin{array}{l}\text { Ovarian, fallopian tube, or primary } \\
\text { peritoneal cancer }\end{array}$ \\
\hline \multirow[t]{3}{*}{ GD2Bi-aATC } & $\begin{array}{l}\text { Barbara Ann Karmanos Cancer } \\
\text { Institute }\end{array}$ & $\begin{array}{l}\text { T cells preloaded with } \\
\text { bsAbs }\end{array}$ & $\mathrm{CD} 3 \times \mathrm{GD} 2$ & Activated T cells & Phase I/II, NCT02173093 & $\begin{array}{l}\text { Children and young adults with } \\
\text { neuroblastoma and osteosarcoma }\end{array}$ \\
\hline & $\begin{array}{l}\text { Barbara Ann Karmanos Cancer I } \\
\text { nstitute }\end{array}$ & & & & $\begin{array}{l}\text { Completed phase I, } \\
\text { NCT00938626 }\end{array}$ & $\begin{array}{l}\text { Multiple myeloma and plasma cell } \\
\text { neoplasm }\end{array}$ \\
\hline & $\begin{array}{l}\text { Barbara Ann Karmanos Cancer } \\
\text { Institute }\end{array}$ & & & & $\begin{array}{l}\text { Completed phase 1, } \\
\text { NCT00244946 }\end{array}$ & $\mathrm{NHL}$ \\
\hline EGFRBi-aATC & $\begin{array}{l}\text { Barbara Ann Karmanos Cancer } \\
\text { Institute }\end{array}$ & $\begin{array}{l}\text { T cells preloaded with } \\
\mathrm{BsAb}\end{array}$ & $\mathrm{CD} 3 \times \mathrm{EGFR}$ & $\begin{array}{l}\text { Autologous activated T cells to } \\
\text { EGFR-positive tumor }\end{array}$ & Phase I/II, NCT02521090 & $\begin{array}{l}\text { Adult brain glioblastoma; adult } \\
\text { gliosarcoma; recurrent brain } \\
\text { neoplasm }\end{array}$ \\
\hline MGD006 & MacroGenics & DART & $\mathrm{CD} 123 \times \mathrm{CD} 3$ & Retargeting of T cells to tumor & Phase I, NCT02152956 & Relapsed/refractory AML \\
\hline MGD007 & MacroGenics & DART & gpA33 $\times$ CD3 & Retargeting of $\mathrm{T}$ cells to tumor & Phase I, NCT02248805 & Colorectal carcinoma \\
\hline MGD010 & MacroGenics & DART & $\mathrm{CD} 32 \mathrm{~B} \times \mathrm{CD} 79 \mathrm{~B}$ & & Phase I, NCT02376036 & Healthy subjects \\
\hline Anti-CEAxanti-DTPA & Nantes University Hospital & scFv-lgG & $\begin{array}{l}\text { CEA } \times \text { di-DTPA- } \\
1311\end{array}$ & Radioimmunotherapy & $\begin{array}{l}\text { Complete phase II, } \\
\text { NCT00467506 }\end{array}$ & Medullary thyroid carcinoma \\
\hline \multirow[t]{2}{*}{ DT2219ARL } & Masonic Cancer Center & $\begin{array}{l}2 \mathrm{scFv} \text { linked to } \\
\text { diphtheria toxin }\end{array}$ & $\mathrm{CD} 19 \times \mathrm{CD} 22$ & $\begin{array}{l}\text { Targeting of protein toxin to } \\
\text { tumor }\end{array}$ & Phase I, NCT00889408 & Leukemia; lymphoma \\
\hline & Masonic Cancer Center & & & & Phase I/II, NCT02370160 & $\begin{array}{l}\text { Relapsed or refractory B lineage } \\
\text { leukemia or lymphoma }\end{array}$ \\
\hline \multirow[t]{2}{*}{ IMCgp100 } & Immunocore Ltd & ImmTAC & CD3 $\times$ gp 100 & T cell recruitment & Phase I, NCT01211262 & Malignant melanoma \\
\hline & & & & & Phase I, NCT02570308 & Uveal melanoma \\
\hline $\begin{array}{l}\text { Indium-labeled IMP- } \\
\text { 205xm734 }\end{array}$ & Radboud University & Unclear & $\begin{array}{l}\text { CEA } \times \text { in-labeled } \\
\text { Peptide }\end{array}$ & Nuclear imaging & Phase I,NCT0018508 & Colorectal cancer \\
\hline LY3164530 & Eli Lilly and Company & OrthoFab-lgG & $\mathrm{MET} \times \mathrm{EGFR}$ & Blockade of 2 receptors & Phase I, NCT02221882 & Neoplasms; neoplasm metastasis \\
\hline OMP-305B83 & OncoMed Pharmaceuticals, Inc. & DVD-Ig & DLL4 $\times$ VEGF & 2-ligand inactivation & Phase I, NCT02298387 & Advanced solid tumor malignancies \\
\hline REGN1979 & Regeneron Pharmaceuticals & Unclear & $\mathrm{CD} 20 \times \mathrm{CD} 3$ & T cell recruitment & Phase I, NCT02290951 & CD20+ B cell malignancies \\
\hline COVA322 & Covagen & IgG-fynomer & TNF- $a \times I L 17 A$ & $\begin{array}{l}\text { Blockade of two proinflammatory } \\
\text { cytokines }\end{array}$ & Phase I/II, NCT02243787 & Plaque psoriasis \\
\hline RG7802 & Hoffmann-La Roche & CrossMab & $\mathrm{CEA} \times \mathrm{CD} 3$ & T cell recruitment & Phase I, NCT02324257 & Solid cancers \\
\hline RG7813 (RO6895882) & Hoffmann-La Roche & ScFv-lgG & $\mathrm{CEA} \times 1 \mathrm{~L} 2$ & The delivery of cytokines & Phase I, NCT02004106 & $\begin{array}{l}\text { Advanced and/or metastatic solid } \\
\text { CEA+ tumors }\end{array}$ \\
\hline RG7221 (RO5520985) & Hoffmann-La Roche & CrossMAb & Ang-2 $\times$ VEGF & 2-ligand inactivation & Phase II, NCT01688206 & Neoplasms \\
\hline
\end{tabular}


Table 1 Bispecific antibodies in clinical trials. Information from ClinicalTrials.gov (https://clinicaltrials.gov) (Continued)

\begin{tabular}{|c|c|c|c|c|c|c|}
\hline RG7716 & Hoffmann-La Roche & CrossMAb & VEGF $\times$ Ang-2 & 2-ligand inactivation & Phase II,NCT02484690 & Wet AMD \\
\hline \multirow[t]{2}{*}{ MM-111 } & Merrimack Pharmaceuticals & HSA body & HER2 $\times$ HER3 & Blockade of 2 receptors & $\begin{array}{l}\text { Completed phase I, } \\
\text { NCT01097460 }\end{array}$ & Breast neoplasms \\
\hline & Merrimack Pharmaceuticals & & & Blockade of 2 receptors & $\begin{array}{l}\text { Completed phase I, } \\
\text { NCT00911898 }\end{array}$ & Her2-amplified solid tumors \\
\hline \multirow[t]{2}{*}{ MM-141 } & Merrimack Pharmaceuticals & scFv-lgG & IGF-IR $\times$ HER3 & Blockade of 2 receptors & Phase I, NCT01733004 & Hepatocellular carcinoma \\
\hline & & & & & Phase II, NCT02399137 & Pancreatic cancer \\
\hline MOR209/ES414 & $\begin{array}{l}\text { Emergent Product Development } \\
\text { Seattle LLC }\end{array}$ & scFv-lgG & $\mathrm{PSMA} \times \mathrm{CD} 3$ & T cell recruitment & Phase I, NCT02262910 & Prostate cancer \\
\hline TargomiRs & University of Sydney & Unclear & $E G F R \times E D V$ & Delivery of nanoparticles & Phase I, NCT02369198 & Recurrent MPM and NSCLC \\
\hline MSB0010841 & Merck KGaA & Nanobody & IL-17A/F & $\begin{array}{l}\text { Blockade of } 2 \text { proinflammatory } \\
\text { cytokines }\end{array}$ & Phase I, NCT02156466 & Psoriasis \\
\hline ALX-0061 & Ablynx & Nanobody & $\mathrm{IL}-6 \mathrm{R} \times \mathrm{HSA}$ & $\begin{array}{l}\text { Blockade of proinflammatory } \\
\text { cytokine, binds to HSA to } \\
\text { increase half-life }\end{array}$ & $\begin{array}{l}\text { Completed phase I/II, } \\
\text { NCT01284569 }\end{array}$ & Rheumatoid arthritis \\
\hline $\begin{array}{l}\text { Ozoralizumab (ATN- } \\
\text { 103) }\end{array}$ & Ablynx & Nanobody & $\mathrm{TNF} \times \mathrm{HSA}$ & $\begin{array}{l}\text { Blockade of proinflammatory } \\
\text { cytokine binds to HSA to } \\
\text { increase half-life }\end{array}$ & $\begin{array}{l}\text { Completed phase II, } \\
\text { NCT01063803 }\end{array}$ & Rheumatoid arthritis \\
\hline AFM13 & University of Cologne & TandAb & $\mathrm{CD} 30 \times \mathrm{CD} 16 \mathrm{~A}$ & Active NK cells & Phase II, NCT02321592 & $\begin{array}{l}\text { Relapsed or refractory Hodgkin } \\
\text { lymphoma }\end{array}$ \\
\hline AFM11 & Affimed GmbH & TandAb & $\mathrm{CD} 30 \times \mathrm{CD} 19$ & Redirecting of $\mathrm{T}$ cells & Phase I, NCT02106091 & $\begin{array}{l}\text { Relapsed and/or refractory CD19- } \\
\text { positive B cell NHL }\end{array}$ \\
\hline \multirow[t]{2}{*}{ SAR156597 } & Sanofi & scFv-lgG & $\operatorname{IL} 4 \times \operatorname{IL} 13$ & $\begin{array}{l}\text { Blockade of proinflammatory } \\
\text { cytokines }\end{array}$ & $\begin{array}{l}\text { Completed phase I/II, } \\
\text { NCT01529853 }\end{array}$ & Idiopathic pulmonary fibrosis \\
\hline & Sanofi & & & & Phase II, NCT02345070 & Idiopathic pulmonary fibrosis \\
\hline
\end{tabular}




\section{lgG-like formats}

1. Quadromas

The quadroma technology relies on the fusion of two distinct hybridomas. The random pairing of Ig heavy and light chains gives rise to bsAbs [9]. In this process, nonfunctional antibodies are also produced. BsAbs produced by quadromas resemble conventional antibodies. Catumaxomab, the first approved bsAb, is produced by a rat/mouse quadroma cell line.

2. Knobs-into-holes

The production of bsAbs with an Fc region poses some challenges such as the formation of undesirable homodimers and other product-related contaminants including mispaired molecules. The "knobs-into-holes" approach has been adopted to tackle these problems by substituting a large amino acid for a small one in the $\mathrm{CH} 3$ domain (the "knob") of one antibody and vice versa (the "hole") of the other antibody [10]. In theory, heterodimers of any two different antibodies can pair in a "knob-andhole" fashion. However, "light chain mispairing" poses another challenge. To circumvent this, several methods have been proposed:

(a) Generating bsAbs with common light chains [11]. This strategy, however, limits binding specificities and is not applicable to all bsAbs.

(b)Expressing the knob- and the hole-containing half-molecules separately in different bacteria [6]. This method would avoid mispairing of the light chains. However, expression in bacterial cells can also result in the loss of key glycosylation modifications, which may affect antibody effector functions (e.g., antibody-dependent cellular cytotoxicity mediated by carbohydratedependent binding to Fcy receptors) [12].

(c) Combining CrossMab and knobs-into-holes strategies to minimize mispairing. In the CrossMab antibody, the $\mathrm{CH}_{1}$ domain of the heavy chain is swapped with the constant CL domain of the corresponding light chain to induce the right pairing of the light chains [13]. By combining knobs-into-holes and CrossMab, Roche generated the bsAb A2V CrossMab with dual specificities for Ang-2 and VEGFA [14].

(d)Introducing additional mutations into $\mathrm{VH}-\mathrm{VL}$ and CH1-CL interfaces. These mutations encourage a heavy chain to preferentially pair with a light chain [15]. One drawback, however, is that it requires extensive mutations in the conserved regions of the antibody.

3. Dual-variable domains Ig (DVD-Ig)

The variable domains of two mAbs are fused in tandem to create a dual-specific IgG-like molecule
[16]. Each Fab of the DVD-Ig binds to two targets. In theory, any pair of mAbs can be used to generate a DVD-Ig molecule. The resulting specific antibodies could be further modified to create molecules with variable valencies and specificities. This technology avoids mispairing of different heavy or light chains, and it improves product homogeneity, yield, and stability. Additionally, the Fc domain facilitates efficient purification. However, there is a potential risk that the binding affinity of the inner variable domain may be reduced [17].

4. IgG-single-chain $\mathrm{Fv}$ ( $\mathrm{scFv}$ )

IgG-scFv is generated by fusing an scFv or a variable single domain to the termini of light or heavy chains. This group of antibodies also includes DVD-Igs.

5. Two-in-one or dual action Fab (DAF) antibodies Antigen-binding sites of DAF antibodies are capable of dual antigen recognition [18]. To achieve this, a template antibody binding to a target antigen is first identified. A mutation is then introduced into the antigen-binding site to recognize a second antigen. Further engineering within the antigen-binding site is needed to facilitate high dual affinity. However, two-in-one antibodies are not capable of binding to two different antigens (epitopes) simultaneously.

6. Half-molecule exchange Human IgG4 antibodies can exchange halfmolecules in the serum, leading to the generation of IgG4 bsAbs by a strategy termed "half-molecule exchange." After the introduction of point mutations into the IgG1 CH3 domain, IgG1 antibodies can undergo half-molecule exchange under controlled conditions to become bsAbs [19]. This strategy also applies to human $\operatorname{IgG} 2$ and $\operatorname{IgG} 3$. The foremost advantage of this method is the separate expression of the parental IgGs, thereby increasing the repertoire of parental antibodies to generate different bsAbs. Thus, this method is an elegant way to produce numerous bsAbs in a short period. Moreover, human bsAbs produced by half-molecule exchange are in their natural formats, with low immunogenicity.

7. $\kappa \lambda$-bodies

One heavy chain and two different light chains (one $\kappa$ and one $\lambda$ ) with different binding specificities can be co-expressed in a single cell. In this way, bsAbs with both $\mathrm{k}$ and $\lambda$ light chains paring with the same heavy chain can be produced [20] and then purified by highly selective affinity resins. The advantages of $\kappa \lambda$-bodies are obvious: firstly, the bsAbs retain the complete human IgG format without modification; secondly, the bsAbs can be easily purified from the mixture of antibodies; thirdly, the bsAbs can be produced at an industrial scale; and finally, the 
purification platform can be applied to any $\mathrm{k} \lambda$-body, thus facilitating parallel development of different bsAbs [20].

\section{Non-IgG-like formats}

\section{1. scFv-based bsAbs}

ScFv comprising only the VL and VH is the basic element for antigen binding. ScFvs can become dimers, trimers, or tetramers depending on linker length, antibody sequence, and external factors [21]. Compared to normal IgG molecules, scFvs exhibit high tumor specificity and tissue penetration; thus, scFv-based bsAbs are favored and have several possible clinical applications.

(a) Tandem scFvs

Two scFvs are connected by a flexible peptide linker such as glycine-serine repeat motifs in a tandem orientation [7]. The short linker prevents intra-chain but not inter-chain pairing of the $\mathrm{VH}$ and the VL domains. The long flexible linker permits antigen-binding sites to rotate freely. The famous bispecific T cell engager (BiTE) technology is based on this format.

(b)Diabody format In the diabody format, the variable domains of two different antibodies are connected by two linkers. The $\mathrm{VH}$ of the first antibody is linked to the VL of the second antibody, and the VL of the first antibody is linked to the $\mathrm{VH}$ of the second antibody. The two linkers increase the stability of the diabody. However, there are trade-offs as the two linkers restrict the mobility of the antigenbinding sites, thus limiting antigen recognizing.

(c) Single-chain diabodies The diabody format can be converted into a single-chain diabody by adding an additional connection linker between the chains.

(d) Tandem diabodies (TandAbs) When two pairs of VL and VH domains are connected in a single polypeptide chain, a tetravalent tandAb is formed.

(e) Dual-affinity retargeting molecules (DARTs) DARTs are created by the association of the $\mathrm{VH}$ of a first variable region linked to the $\mathrm{VL}$ on a second chain, and the $\mathrm{VH}$ of the second variable region linked to the $\mathrm{VL}$ on the first chain in a $\mathrm{VL}_{\mathrm{A}}-\mathrm{VH}_{\mathrm{B}}+\mathrm{VL}_{\mathrm{B}}-\mathrm{VH}_{\mathrm{A}}$ configuration [22]. An inter-chain disulfide bond is introduced to stabilize the diabody [22]. The small size of DARTs makes them prone to elimination. To avoid this, MacroGenics fused an Fc fragment to the DARTs to prolong their serum retention time [23].

\section{Nanobodies}

Nanobodies are the smallest naturally occurring antibodies and consist only of a heavy chain $(15 \mathrm{kDa})$ [24]. A nanobody can bind to the corresponding antigen in the absence of a light chain. Nanobodies with different binding specificities obtained from llamas and camels have been connected with short linkers to create bsAbs [25].

3. Dock-and-lock (DNL) method

In this method, antibody fragments are fused to heterodimerizing proteins such as cAMP-dependent protein kinase A (PKA) and A kinase-anchoring protein (AKAP). When the proteins heterodimerize, bispecific molecules are generated [26].

4. Other bispecific/multispecific molecules ScFvs can also be connected to other molecules such as cytokine TNF- $\alpha$ (TNF- $\alpha$ naturally exists in trimeric form) and the trimerization domain of collagen XV or XVIII as well as zipper dimerization domains (Fos or Jun) to generate multivalent molecules [6].

\section{Half-life extension strategies}

ScFv-based bsAbs have many advantages including ease of manufacturing and enhanced tissue penetration. Additionally, they can bind to epitopes that may be sterically inaccessible to antibodies in complete IgG format. Further, they are less immunogenic owing to the lack of an Fc region, thus avoiding uptake by FcR. However, scFvbased bsAbs suffer from several drawbacks due to their short half-lives, such as rapid blood clearance, fast offrates, and poor retention times in targeted sites (e.g., tumors). In clinical applications, a short serum half-life increases the number of applications and the doses of therapeutic agents [27]. Thus, extension of the serum half-life can be both economically and therapeutically beneficial. Several strategies are available to extend serum half-lives of bsAbs, such as:

1. Polyethylene glycol (PEG)ylation Attaching highly flexible, hydrophilic molecules, such as PEG, will increase the hydrodynamic volume of the bsAbs, thus improving their serum half-lives. However, the number and size of attached PEG chains can lead to partial inactivation or decreased binding affinity of the antibodies [28]. Conjugating a single PEG chain using a site-directed approach appears to be an ideal strategy [27].

2. Fusion with human serum albumin (HSA) or an albumin-binding moiety Fusion of scFvs to HSA or an albumin-binding moiety can prolong their serum half-lives. Additionally, HSA interacts with FcRn without altering the antigenbinding affinity. This strategy has been widely adopted 
by antibody engineers. Albumin fusion/binding does not only increase the molecule size, but it also promotes recycling of the bsAbs, extending their halflives. Albumin taken up by cells will first bind to the FcRn of the early endosome, thus escaping degradation. Then, albumin is redirected to the plasma membrane and released back into the blood plasma [27]. Merrimack Pharmaceuticals developed MM-111 bsAb by binding scFvs to HSA. Ozoralizumab (ATN-103, Ablynx) is a trivalent bispecific nanobody derived from a camelid heavy chain with a molecular weight of $38 \mathrm{kDa}$. In theory, molecules of such small size are easily eliminated by the kidneys. To address this problem, ozoralizumab has been designed to bind to HSA while retaining its binding specificity for TNF- $\alpha$ [29].

3. Fc fragment fusion

Some antibody engineers fuse an Fc fragment to scFv-based bsAbs. The Fc fragment not only improves the molecule size, but it also promotes recycling through FcRn. MacroGenics developed Fc-bearing DART MGD007 for patients with colon cancer.

4. Multimerization Multimerization is another strategy to optimize the half-life by modulating the sizes and the binding values of a bsAb.

\section{Clinical applications of bsAbs}

BsAbs redirecting immune effector cells to the proximity of tumor cells

Cytotoxic $\mathrm{T}$ lymphocytes play an important role in the immune response against cancer [30]. However, tumorspecific $\mathrm{T}$ cell responses are limited by immune escape mechanisms utilized by tumor cells during immunoediting. Progress in immunotherapy over the past years has allowed overcoming this challenge. One strategy to harness the immune cells is to take advantage of bsAbs to kill tumor cells. Several bsAbs in clinical development are designed to redirect $\mathrm{T}$ cells to tumor cells [31]. This process is accompanied by the formation of a transient cytolytic synapse between the $\mathrm{T}$ cell and the targeted tumor cell. The subsequent activation and proliferation of $\mathrm{T}$ cells leads to tumor cells lysis [32]. Besides $\mathrm{T}$ cells, other immune cells such as macrophages, monocytes, granulocytes, and natural killer (NK) cells also exert tumor-killing effects. A number of bsAbs including Triomab, BiTE, DART, and FynomAb provide new treatment options for patients.

1. Triomab antibodies redirecting $\mathrm{T}$ cells to tumor cells Triomab antibodies are produced with high yield and purity by mouse-rat hybridomas. The desired bsAbs are mixed with by-products such as monospecific antibodies, and L-chain mispairing further complicates purification. Given the fact that light (heavy) chains from rat and mouse associate preferentially, $\mathrm{L} / \mathrm{H}$-chain mispairing can be reduced to $4-10 \%$ [33]. The bsAbs are easily purified by protein A [5]. Triomab antibodies are trifunctional, with one arm binding to tumor-associated antigen, the second arm binding to CD3 on T cells, and the chimeric Fc region preferentially recognizing type I

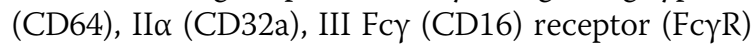
on accessory cells such as macrophages, dendritic cells, and NK cells. T cells are then activated, accompanied by the release of $\mathrm{T}$ cell cytokines such as TNF- $\alpha$ and IFN- $\gamma$. Additionally, Fc $\gamma R$-positive accessory cells are redirected to tumor cells with the release of high levels of proinflammatory cytokines such as IL-6, IL-12, GM-CSF, and DC-CK1 [34]. Tumor cells are killed through $\mathrm{T}$ cell-mediated lysis and ADCC as well as through phagocytosis by activated accessory cells [9] (Fig. 2).

Catumaxomab belongs to the Triomab family and was the first bsAb to be approved for cancer treatment. It is produced by co-expression of rat IgG2b and mouse IgG2a in a single host cell. Compared to the BiTE, the IgG-like bsAb has a longer serum half-life. Patients receive intraperitoneal infusion of 10-150 $\mu \mathrm{g}$ four to five times over 9-13 days [8]. Most patients develop a tolerable humoral immune response against catumaxomab. This antidrug response correlates with a favorable clinical outcome. This protection relies on the presence of the chimeric Fc domain of catumaxomab, which evokes an immunogenic reaction [9]. Potential adverse events suffered by patients include transient fever, nausea, and vomiting. Most adverse events may be attributed to cytokine-release-related symptoms and are reversible [9]. Catumaxomab is approved in the European Union for EpCAM-positive carcinoma patients for whom standard therapy is not feasible. Catumaxomab is currently in clinical trials for application to ovarian cancer, gastrointestinal cancer, non-small cell lung cancer, breast cancer, and peritoneal carcinomatosis [35].

Other Triomab members include ertumaxomab and FBTA05. Ertumaxomab targets HER2/neu, a validated breast tumor biomarker. By retargeting $\mathrm{T}$ cells to HER2/neu-overexpressing cells, ertumaxomab can kill tumor cells with low surface expression of HER2/neu as well [36]. In a phase I study, five out of 15 metastatic breast cancer patients receiving ertumaxomab treatment showed an antitumor response [37]. FBTA05 specifically binds to CD20 on B cells and CD3 on T cells and is in phases I-II trials in patients with CD20-positive B cell malignancies [38]. 


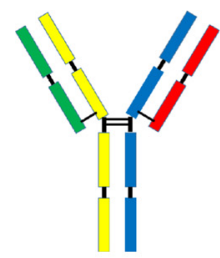

Quadroma

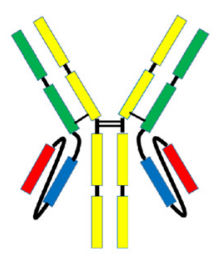

IgG-scFV
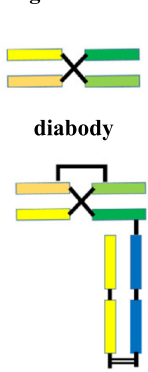

DART-Fc

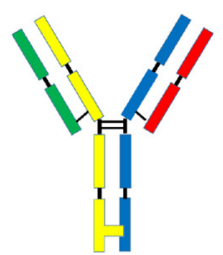

Knobs-into-holes

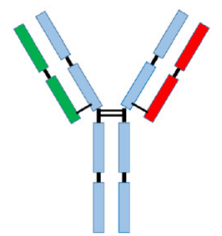

K $\lambda$ body

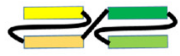

Tandem scFV

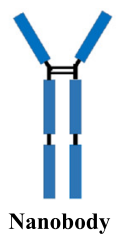

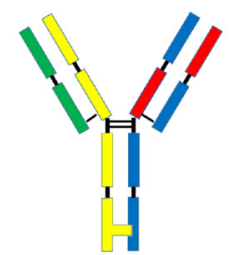

Knobs-into-holes and CrossMAb

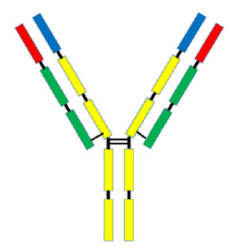

Dual-variable domains

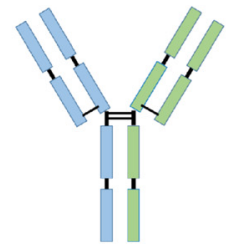

Half-molecule exchange

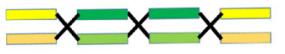

Tandem diabody
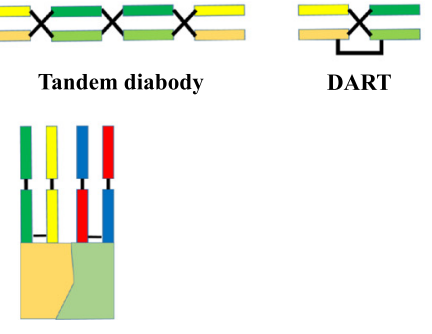

Dock-and-lock

Fig. 1 Molecular formats of bispecific antibodies

2. BiTEs redirecting $\mathrm{T}$ cells to tumor cells

The BiTE platform is utilized to develop tandem scFv bsAbs. Blinatumomab binds to CD3 on T cells and CD19-expressing B cell malignancies [39]. It is the first bsAb approved by the US Food and Drug Administration (FDA) for acute B cell lymphoblastic leukemia and has a small size of $55 \mathrm{kDa}$ [40]. Additionally, it is in phases II and III for acute lymphoblastic leukemia (ALL), phase II for diffuse large B cell lymphoma (DLBCL), and phase I for non-Hodgkin lymphoma (NHL). Blinatumomab shows potent tumor-killing capacity by redirecting $\mathrm{T}$ cells to tumor cells (Fig. 3). The resulting influx of various granzyme proteases provide essential components for the cytolytic synapse formed between the T cells and target cells [41]. Meanwhile, $\mathrm{T}$ cells begin to proliferate and release cytokines such as TNF- $\alpha$, IFN- $\gamma$, IL-6, IL-2, IL-4, and IL-10 [42]. The BiTE molecule is quite potent in redirecting $\mathrm{T}$ cells to CD19 positive lymphoma cells at very low concentrations of 10 to $100 \mathrm{pg} / \mathrm{ml}$. Doses of $>15 \mu \mathrm{g} / \mathrm{m}^{2} /$ day lead to the depletion of tumor cells in vivo. Blinatumomab has a serum half-life of less than $2 \mathrm{~h}$. Patients receive the BiTE infusion via an implanted port system and have to stay under observation for 3-7 days. The treatment resulted in an impressive $43 \%$ complete response rate and a median overall survival of 6.1 months in a phase II trial in patients with high-burden relapsed or refractory B cell ALL (B-ALL) [23]. Blinatumomab has some disadvantages, as some patients suffer from neurotoxicity and show symptoms of cytokine-release syndrome [23]. Due to its small size, blinatumomab can be easily eliminated by the kidneys, and patients need to change the infusion bag every $48 \mathrm{~h}$ [32]. It should be noted that some patients receiving blinatumomab develop drug resistance [43]. The underlying mechanisms include, but are not limited to, loss of CD19, extramedullary relapse, and upregulation of programmed death-ligand 1 on tumor cells [43]. Besides blinatumomab, some other BiTEs such as solitomab (anti-CD3 $\times$ EpCAM, completed phase I for solid tumors), MEDI-565 (anti-CD3 $\times$ CEA, completed phase I for gastrointestinal adenocarcinoma), and BAY2010112 (anti-CD3 $\times$ PSMA, phase I for prostate cancer) are also under investigation [44].

3. DARTs retargeting $\mathrm{T}$ cells to tumor cells The DART technology is used to produce bsAbs with increased stability and reduced immunogenicity owning to minimal linker size. Unlike BiTEs, the 


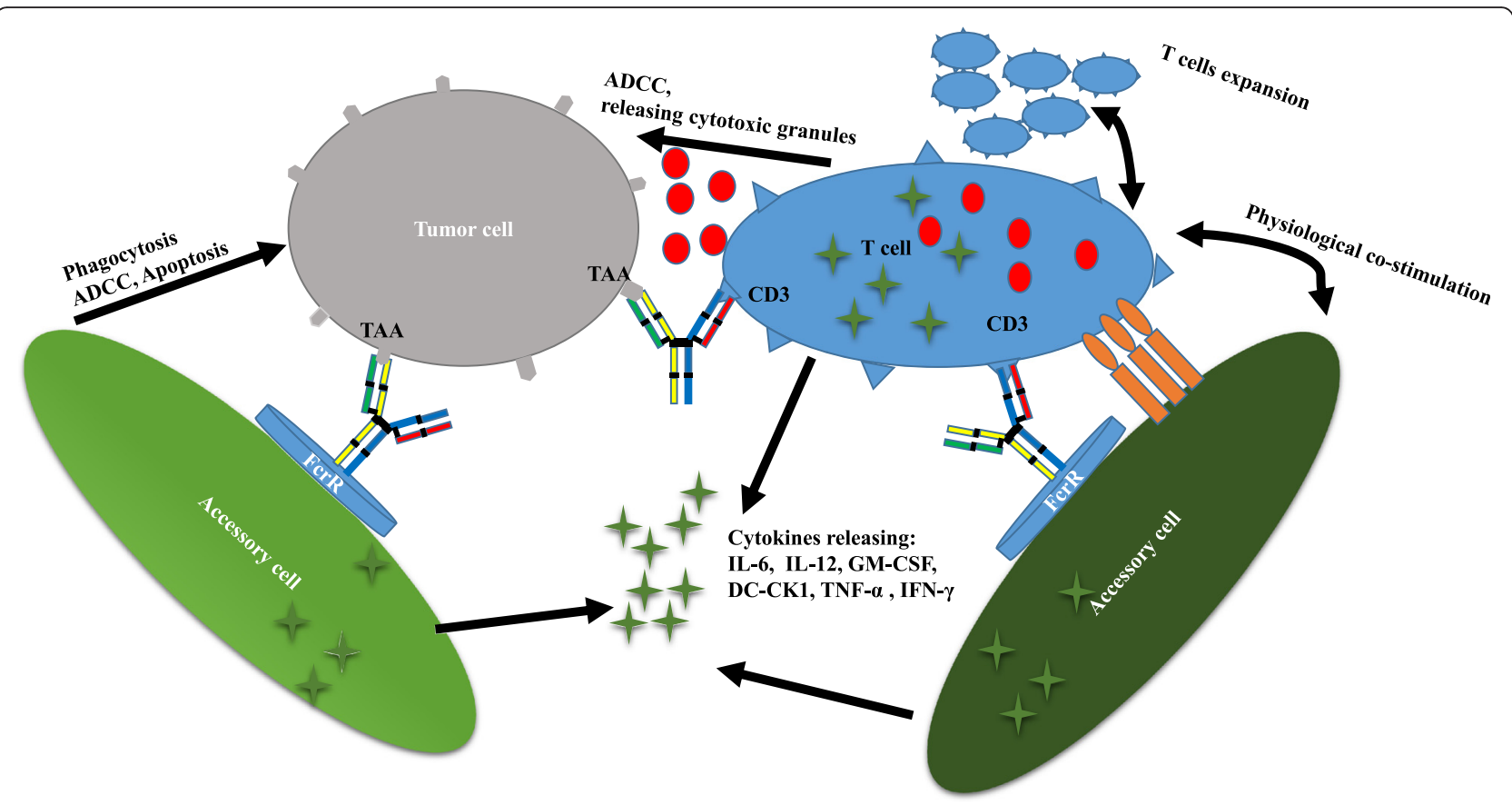

Fig. 2 Triomab ${ }^{\oplus}$ antibodies redirect T cells and other accessory cells to a tumor cell

covalent linkage between the two chains of DARTs limits the freedom of the antigen-binding sites. Therefore, DARTs are structurally compact and can form stable contacts between target and effector cells. Moore et al. demonstrated the CD19 × CD3 DART to be more potent than the BiTE molecule in redirected killing of $B$ cell lymphoma [22]. This may be explained by the fact that the binding affinity of the DART format for CD3 is higher and the dissociation rate constant for CD19 is lower [45]. However, with only one study conducting a side-by-side comparison available, it is hard to conclude which format is better. More clinical trials are needed to assess the superiority between the DART and BiTE formats [45]. However, Moore et al. demonstrated that DART could be an alternate $\mathrm{T}$ cell activator.

Both mammalian and prokaryotic systems can be used for antibody expression. To date, more than 70 DART products have been generated [5]. Various mechanisms including activation of tumor-killing effector cells, targeting of receptors or cytokines, and binding to pathogenic epitopes are involved in DARTs function. Two products are currently in clinical trials. MGD006 is designed to treat acute myeloid leukemia (AML) by redirecting $\mathrm{T}$ cells to kill leukemic cells [46]. It has two specific targeting arms: one for CD123 on leukemic stem cells and the other one for CD3 on T cells. Currently, MGD006 is in phase I in patients with AML.
Unlike MGD006, MGD007 belongs to the Fcbearing DARTs. Evidently, the fusion of the Fc fragment avoids easy clearance and prolongs the serum retention time by FcRn-dependent recycling. MGD007 redirects T cells to gpA33-positive colon cancers and mediates potent lysis of gaA33-positive cells [47]. It is now in phase I trial in patients with colorectal cancer.

4. TandAbs redirecting immune cells to kill tumor TandAbs comprise four binding sites without an Fc fragment. Larger than BiTEs, they have a molecular weight of about $114 \mathrm{kDa}$ [48]. Therefore, they have longer serum half-lives than BiTEs and diabodies. TandAbs can be produced in bacterial and mammalian cells. A major difference with BiTEs is that TandAbs exhibit bivalent binding activity for each specificity-an important means to increase target-binding affinity. They are effective at retargeting immune cells to tumor cells and inducing cell lysis.

AFM13 is a tetravalent bsAb with a murine antiCD30 domain. It specifically targets CD16A on NK cells and macrophages [49]. CD16A is an activating receptor involved in tumor-cell killing. In Hodgkin's patients, CD30 is highly expressed by Hodgkin and Reedsternberg cells. AFM13 recruits and activates NK cells to induce lysis of CD30-positive tumor cells. Dose-limiting toxicity such as hemolytic anemia may be seen in patients receiving AFM13. Further, an anti-drug response has been observed in some patients [49]. Currently, AFM13 is in clinical 


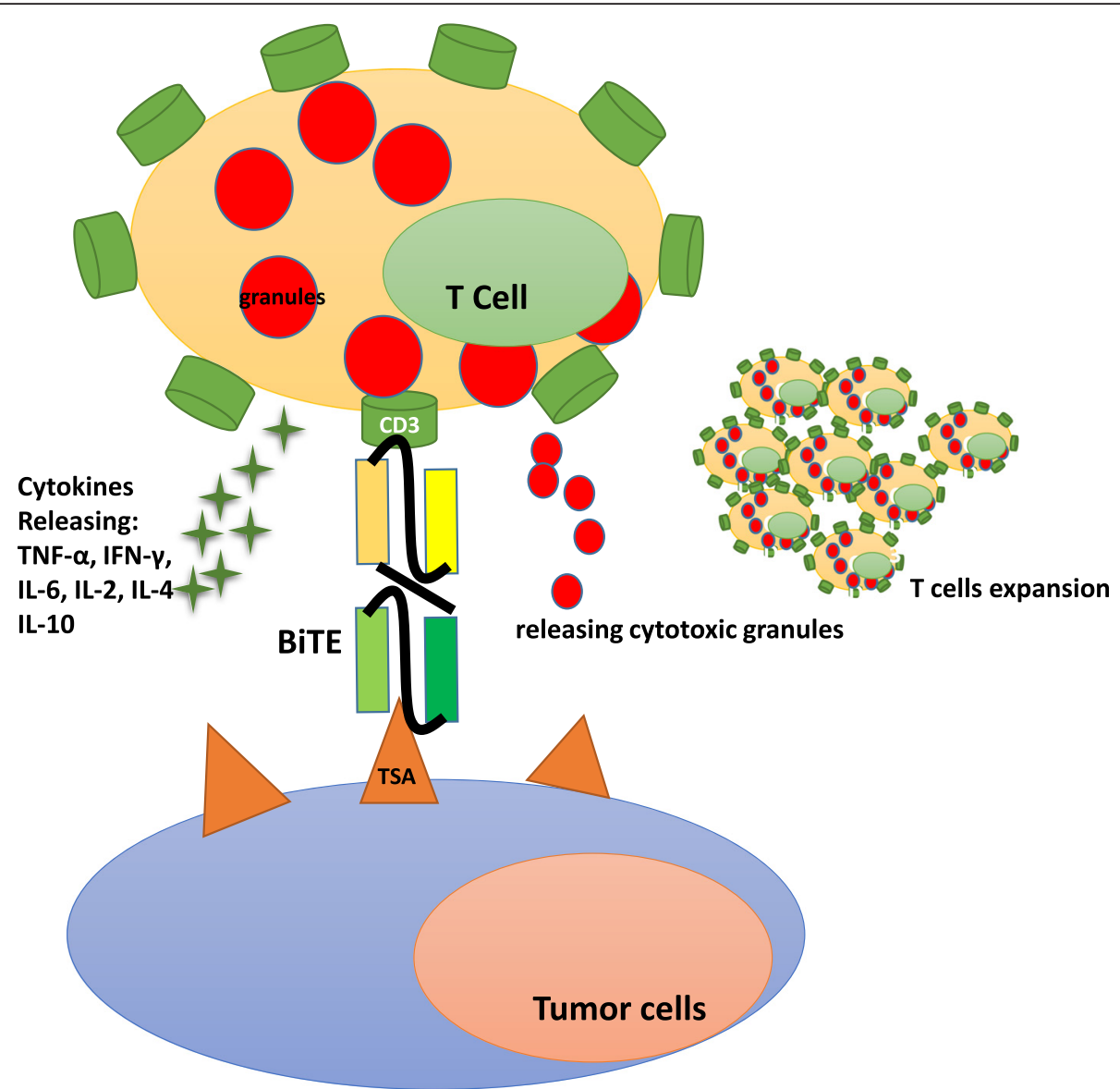

Fig. 3 BiTE $^{\oplus}$ antibodies redirect $T$ cells to a tumor cell

phase II in patients with Hodgkin's disease. Unlike AFM13, AFM11 redirects T cells to CD19 positive lymphomas. AFM11 is in clinical phase I trial in patients with non-Hodgkin's lymphoma and ALL.

\section{BsAbs blocking signaling pathways}

As a subclass of cell-surface growth factor receptors, receptor tyrosine kinases (RTKs) are critically involved in oncogenesis [50]. Several monospecific RTK-targeting antibodies including herceptin (for metastatic breast cancer), imatinib (for CML and GIST), gefitinib (for NSCLC), and cetuximab (for colorectal cancer) have been approved for cancer therapeutics [50]. However, multiple signaling pathways exerting unique or overlapping functions are involved in pathogenesis. Thus, simultaneously neutralizing two targets with one molecule exhibits unique appeal and offers better treatment potential than mAbs.

1. HSA body bsAbs MM-111 is a bsAb with two scFvs fused to modified HSA [51]. It targets the HER2/HER3 signaling pathways simultaneously. HER2 is a validated target for numerous cancers. HER3 signaling is an important mechanism of drug resistance to HER2 inhibitor. Dual targeting of HER2/HER3 can lead to a more effective response. MM-111 alone or with trastuzumab is in clinical trials in patients with HER2-postitive solid tumors [27].

2. $\mathrm{ScFv}-\mathrm{IgGs}$

MM-141 is another bsAb targeting the insulin-like growth factor I receptor (IGF-IR) and HER3. Unlike MM-111, MM-141 is an IgG-like bsAb with two scFvs fused to the constant region of an IgG. Both IGF-IR and HER3 activate the PI3K/AKT/mTOR axis-a mechanism for targeted resistance. MM-141 binds to IGF-IR and HER3, thus blocking the downstream resistance mechanism [52]. MM-141 is currently in phase I study in patients with hepatocellular carcinoma.

3. Two-in-one antibody

Duligotuzumab is a two-in-one (DAF) phage-derived humanized antibody. It binds to EGFR and HER3, resulting in the inhibition of the downstream signaling pathways of HER-family [53]. Deregulated EGFR- and HER3-dependent signaling is involved in 
the pathogenesis of human cancers such as head and neck and colorectal cancers. Patients who receive EGFR inhibitor cetuximab treatment often develop anti-EGFR resistance. When used in combination with radiation, duligotuzumab overcomes drug resistance and enhances the effects of radiation. Currently, duligotuzumab is in clinical trials in patients with epithelial tumors and neck squamous cell carcinoma. Duligotuzumab exhibited similar antitumor activity as cetuximab in a phase II study in patients with recurrent or metastatic neck squamous cell carcinoma [54]. It should be noted that patients receiving duligotuzumab are at high risk of adverse effects such as febrile neutropenia, hypokalemia, nausea, and dehydration [55].

\section{BsAbs targeting tumor angiogenesis}

Angiogenesis is a key process in tumor growth and metastasis. Multiple angiogenic factors including endothelial growth factor receptor 2 (VEGFR2), VEGFR3, endothelial growth factor A (VEGFA), angiopoietins, and platelet-derived growth factors (PDGFs) are involved in tumor angiogenesis. Many cancer therapies disrupt angiogenesis by depleting these proteins [56]. Dual targeting of angiogenic factors leads to superior outcomes [57].

RG7221 is a human IgG1-like CrossMab targeting two key angiogenic factors, VEGFA and angiopoietin-2 (Ang-2). In preclinical models, RG7221 strongly inhibited angiogenesis and tumor growth, with superior effect as comparing to single-pathway inhibitors [14]. Currently, RG7221 is in phase II study in patients with colorectal cancer. According to clinical data from the phase I study, patients receiving RG7221 treatment may suffer from hypertension, asthenia, headache and fatigue [14].

RG7716 is a similar CrossMab, which was also designed to block VEGFA and Ang2, and is in phase II study in patients with wet type age-related macular degeneration (wet AMD).

\section{BsAbs blocking cytokines}

Several cytokines have been identified as key mediators of inflammatory and autoimmune diseases [58]. Therefore, blockage of these cytokines has treatment potential. For example, the inhibition of TNF- $\alpha$ exerts profound therapeutic effects on psoriasis, psoriatic arthritis, Crohn's disease, ulcerative colitis, juvenile arthritis, and many other diseases [59]. Other validated cytokines include IL-6, IL-17, IL-1, IL-12, TGF- $\beta$, IL-4, and IL-13. [59-62].

\section{Nanobodies}

Ozoralizumab (ATN-103) is a small trivalent, bispecific nanobody developed by Ablynx with high affinity for
TNF- $\alpha$ and HSA. Albumin binding increases its serum half-life [63]. Ozoralizumab completed phase II clinical trial in patients with rheumatoid arthritis (RA), and it showed significant improvement in RA. Ozoralizumab exhibits specific molecular features such as small size, low immunogenicity, and long serum half-life, making it appealing for clinical applications.

Similar nanobodies developed by Ablynx include ALX0061 against IL-6R/HSA for RA and ALX-0761 against IL-17A/F for inflammatory disease $[64,65]$.

\section{SAR156597}

SAR156597 is a tetravalent bispecific tandem IgG that simultaneously binds to IL-13 and IL-4. Structurally, SAR156597 is an IgG molecule (anti-IL4 antibody) with its $\mathrm{N}$ terminus fused to the variable domain of an antiIL13 antibody [66]. It has completed phase I/II clinical investigation for idiopathic pulmonary fibrosis [67].

\section{BsAbs as delivery vehicles}

An interesting application of bsAbs is the delivery of payloads such as drugs, radiolabels, and nanoparticles. The payloads are administered once the unbound bispecific molecules are cleared from the bloodstream. Bispecific molecules can be used to enrich payloads in tumor sites [26, 68-70]. This strategy significantly prolongs the serum retention time and improves the tumor/blood ratio.

\section{DNL}

The bispecific TF2 built made by the DNL method is used for tumor imaging and radioimmunotherapy. It specifically binds to CEA and ${ }^{99} \mathrm{~m}$ T-labeled hapten histamine-succinyl-glycine (HSG). In the preclinical trial, TF2 was first injected, and ${ }^{99 \mathrm{~m}}$ T-labeled HSG was then administered after the clearance of the bsAb from the blood. A high tumor/blood ratio was observed with high tumor uptake of ${ }^{99 \mathrm{~m}} \mathrm{~T}$. At present, TF2 is in phase I study in patients with colorectal cancer [71]. Other applications of TF2 include targeting against $177 \mathrm{Lu}$ HSG/ ${ }^{111 \mathrm{In}} \mathrm{HSG}$ and CEA for radioimmunotherapy in patients with colorectal neoplasms and targeting against ${ }^{68 \mathrm{Ga}} \mathrm{HSG}$ and CEA for immuno-positron emission tomography.

\section{BsAbs in preclinical development}

1. BsAbs crossing the blood-brain barrier A promising application of bsAbs is to cross the blood-brain barrier (BBB) to target pathogenesis mediators in neurological diseases [72]. The BBB forms a forbidden zone for monospecific antibody therapy. Couch et al. designed a bsAb that binds to transferrin receptor (TfR) and $\beta$-site APP-cleaving 
enzyme 1 (BACE1) to overcome this hurdle [73]. TfR is highly expressed on the surface of brain endothelium. BACE1 is an aspartyl protease that contributes to the pathogenesis of Alzheimer's disease, and targeting BACE1 has been a longsought-after strategy for treating Alzheimer's disease [74]. After binding to TfR, the circulating bsAb is transported into the brain via receptor-mediated transcytosis. The affinity between the bsAb and TfR is weak; therefore, bsAb can be released from the endothelium and enter the brain to target disease mediator BACE1 with the other binding arm. A preclinical study showed that the bsAb could alleviate disease syndromes [74]. Several other bsAbs are being developed to cross the BBB via transferrin receptormediated transcytosis [72].

2. BsAbs for diagnostic assays BsAb can be used in diagnostic assays. Typically, a bsAb is designed to bind a specific antigen and a detecting moiety such as horseradish peroxidase. Therefore, bsAb can function as a cross-linker, binding an antigen and reporter molecules simultaneously. In an immunoassay, a monospecific capture antibody is immobilized onto a solid surface and binds to the corresponding antigen in serum. BsAb is then added to bind the captured antigen and a reporter molecule. Such bsAb-based immunoassays have been applied in patients infected with tuberculosis, hepatitis B, Escherichia coli, Bordetella pertussis, SARS, and other infectious diseases [75]. Additionally, bsAbs have been used in other diagnostic applications such as immunohistochemistry and radioimmunodiagnosis [76]. Compared to monospecific antibodies, bsAbs simplify diagnostic assays and reduce false-positive reactions [76, 77]. BsAb-based diagnostics specifically detect bacterial or viral antigens, instead of antibodies, thereby enabling early-stage detection.

3. BsAbs for the treatment of pathogens Due to the overusing broad-spectrum antibiotics, many pathogenic strains have become antibiotic resistant, and some have even become resistant to multiple antibiotics and chemotherapeutic agents. The rise of multi-drug resistance poses a major threat to the development of new antibiotic classes. The development of bsAbs offers a strategy to overcome this problem. Recently, a study reported the effectiveness of a new bsAb, BiS4 $\alpha \mathrm{Pa}$, to treat Pseudomonas aeruginosa infections [78]. P. aeruginosa remains a significant contributor to hospitalacquired pneumonia and mortality in patients with cystic fibrosis. Antibiotics against single epitopes of $P$. aeruginosa are ineffective due to drug resistance. The bispecific BiS4 $\alpha \mathrm{Pa}$ was designed to bind to Psl, an extracellular polysaccharide that plays an important role in immune evasion and biofilm formation, with one binding arm, and to PcrV, a component involved in the secretion of virulence factors, with the other binding arm. The superior protective activity of $\mathrm{BiS} 4 \alpha \mathrm{Pa}$ was proven in an animal study, and $\mathrm{BiS} 4 \alpha \mathrm{Pa}$ is now a clinical candidate for the treatment of $P$. aeruginosa [79]. Besides BiS4 $\alpha \mathrm{Pa}$, various other bsAbs have been developed to redirect cytotoxic $\mathrm{T}$ lymphocytes to kill HIV [80], protect against HBV infection [81], or promote the clearance of bacteriophages [82].

\section{Conclusions}

BsAbs can not only bridge therapeutics (e.g., $\mathrm{T}$ cells, drugs) and targets (e.g., tumor) but also simultaneously block two different pathogenic mediators [83]. In the near future, bsAbs might improve treatment options against cancer, autoimmune diseases, and inflammatory diseases. Two bsAbs have been approved with an impressive treatment profile. The success of bsAbs has captured the attention of pharmaceutical companies, with different companies devising new formats.

Success aside, several critical hurdles remain, as only few formats have successfully moved into clinical trials. Large-scale production and purity are long-term pursuits. The ideal platform should encompass the entire development process from discovery and preclinical studies to clinical material production, to allow rapid discovery of potent lead bsAbs and purification of clinical-grade bsAbs in a short time. Thus, simplifying the structure and production procedure and utilizing a powerful production platform are the keys when designing a bsAb format. The identification of target pairs and bsAbs with potential synergistic effects also poses a big challenge, necessitating a high-throughput approach. Moreover, immunogenicity is a complex issue in drug design and development. In clinical trials, adverse effects are often reported and hamper the success of bsAbs. For example, toxicity of the bispecific $4 \mathrm{G} 7 \times \mathrm{H} 22$ leads to the termination of its clinical study (https://clinical trials.gov/ct2/show/NCT00014560). Most adverse effects are mainly caused by a "cytokine storm." With the development of bsAbs, there is hope for the availability and approval of more therapeutic alternatives in future.

\footnotetext{
Abbreviations

ADCC: antibody-dependent cell-mediated cytotoxicity; ADCP: antibodydependent cellular phagocytosis; ALL: lymphoblastic leukemia; BACE1: $\beta$-site APP-cleaving enzyme 1; BiTE: bispecific T cell engager; BsAb: bispecific antibody; CDC: complement-dependent cytotoxicity; DARTs: dual-affinity retargeting molecules; DNL: dock-and-lock; IgG: immunoglobulin G; mAb: monoclonal antibody; MPM: malignant pleural mesothelioma; NHL: non-Hodgkin lymphoma; NSCLC: non-small-cell lung cancer; scFv: single-chain Fv; TandAbs: tandem diabodies; wet AMD: wet type age-related macular degeneration.
} 


\section{Competing interests}

The authors declare that they have no competing interests.

\section{Authors' contributions}

$J$ designed and revised the manuscript. GF wrote the manuscript. ZW prepared the figures. MH proofread the manuscript. All authors read and approved the final manuscript.

\section{Acknowledgements}

This work is supported by the National Natural Science Foundation of China Grant 81271915

\section{Author details}

${ }^{1}$ National Center for Clinical Laboratories, Beijing Hospital, No 1 Dahua Road, Dongdan, Beijing 100730, China. ${ }^{2}$ Graduate School, Peking Union Medical College, Chinese Academy of Medical Sciences, Beijing 100730, China. ${ }^{3}$ Shunyi District Maternal and Child Health Hospital of Beijing City, Beijing 101300, China.

\section{Received: 15 October 2015 Accepted: 9 December 2015} Published online: 21 December 2015

\section{References}

1. Ecker DM, Jones SD, Levine HL. The therapeutic monoclonal antibody market. mAbs. 2015;7(1):9-14

2. Suresh T, Lee LX, Joshi J, Barta SK. New antibody approaches to lymphoma therapy. J Hematol Oncol. 2014;7(1):58.

3. Kontermann R. Dual targeting strategies with bispecific antibodies. mAbs. 2012:4(2):182-97.

4. Regales L, Gong Y, Shen R, de Stanchina E, Vivanco I, Goel A, et al. Dual targeting of EGFR can overcome a major drug resistance mutation in mouse models of EGFR mutant lung cancer. J Clin Invest. 2009;119(10):3000-10.

5. Dhimolea E, Reichert JM. World bispecific antibody summit, September 27-28, 2011, Boston, MA. mAbs. 2012;4(1):4-13.

6. Spiess C, Zhai Q, Carter PJ. Alternative molecular formats and therapeutic applications for bispecific antibodies. Mol Immunol. 2015:67(2):95-106.

7. Chames P, Baty D. Bispecific antibodies for cancer therapy. mAbs. 2009:1(6):539-47.

8. Kontermann RE, Brinkmann U. Bispecific antibodies. Drug Discov Today. 2015;20(7):838-47

9. Seimetz D, Lindhofer $H$, Bokemeyer C. Development and approval of the trifunctional antibody catumaxomab (anti-EpCAM $\times$ anti-CD3) as a targeted cancer immunotherapy. Cancer Treat Rev. 2010;36(6):458-67.

10. Shatz W, Chung S, Li B, Marshall B, Tejada M, Phung W, et al. Knobs-intoholes antibody production in mammalian cell lines reveals that asymmetric afucosylation is sufficient for full antibody-dependent cellular cytotoxicity. mAbs. 2013:5(6):872-81.

11. Merchant AM, Zhu Z, Yuan JQ, Goddard A, Adams CW, Presta LG, et al. An efficient route to human bispecific IgG. Nat Biotechnol. 1998;16(7):677-81.

12. Onitsuka M, Kawaguchi A, Asano R, Kumagai I, Honda K, Ohtake H, et al. Glycosylation analysis of an aggregated antibody produced by Chinese hamster ovary cells in bioreactor culture. J Biosci Bioeng. 2014;117(5):639-44.

13. Schaefer W, Regula JT, Bähner M, Schanzer J, Croasdale R, Dürr H, et al. Immunoglobulin domain crossover as a generic approach for the production of bispecific lgG antibodies. Proc Natl Acad Sci. 2011;108(27):11187-92.

14. Kienast Y, Klein C, Scheuer W, Raemsch R, Lorenzon E, Bernicke D, et al. Ang-2VEGF-A CrossMab, a novel bispecific human lgG1 antibody blocking VEGF-A and Ang-2 functions simultaneously, mediates potent antitumor, antiangiogenic, and antimetastatic efficacy. Clin Cancer Res. 2013;19(24):6730-40.

15. Lewis SM, Wu X, Pustilnik A, Sereno A, Huang F, Rick HL, et al. Generation of bispecific $\lg G$ antibodies by structure-based design of an orthogonal Fab interface. Nat Biotechnol. 2014;32(2):191-8.

16. Wu C, Ying H, Bose S, Miller R, Medina L, Santora $L$, et al. Molecular construction and optimization of anti-human $\mid L-1 \alpha / \beta$ dual variable domain immunoglobulin (DVD-lgTM) molecules. mAbs. 2009;1(4):339-47.

17. Tarcsa E, Fraunhofer W, Ghayur T, Salfeld J, Gu J. Dual-variable domain immunoglobulin (DVD-lg ${ }^{T M}$ ) technology: a versatile, novel format for the next generation of dual-targeting biologics. In: Kontermann RE, editor. Bispecific Antibodies. Berlin, Heidelberg: Springer Berlin Heidelberg; 2011. p. 171-85.
18. Eigenbrot C, Fuh G. Two-in-one antibodies with dual action Fabs. Curr Opin Chem Biol. 2013;17(3):400-5.

19. Labrijn AF, Meesters Jl, Priem $P$, de Jong RN, van den Bremer ETJ, van Kampen MD, et al. Controlled Fab-arm exchange for the generation of stable bispecific lgG1. Nat Protoc. 2014;9(10):2450-63.

20. Fischer N, Elson G, Magistrelli G, Dheilly E, Fouque N, Laurendon A, et al. Exploiting light chains for the scalable generation and platform purification of native human bispecific lgG. Nat Commun. 2015;6:6113.

21. Le Gall F, Kipriyanov SM, Moldenhauer G, Little M. Di-, tri- and tetrameric single chain Fv antibody fragments against human CD19: effect of valency on cell binding. FEBS Lett. 1999:453(1-2):164-8.

22. Moore PA, Zhang W, Rainey GJ, Burke S, Li H, Huang L, et al. Application of dual affinity retargeting molecules to achieve optimal redirected T-cell killing of B-cell lymphoma. Blood. 2011;117(17):4542-51.

23. Garber K. Bispecific antibodies rise again. Nat Rev Drug Discov. 2014;13(11):799-801

24. Revets $\mathrm{H}$, Baetselier PD, Muyldermans S. Nanobodies as novel agents for cancer therapy. Expert Opin Biol Ther. 2005;5(1):111-24.

25. Conrath KE, Lauwereys M, Wyns L, Muyldermans S. Camel single-domain antibodies as modular building units in Bispecific and bivalent antibody constructs. J Biol Chem. 2001:276(10):7346-50.

26. Goldenberg DM, Rossi EA, Sharkey RM, McBride WJ, Chang C-H. Multifunctional antibodies by the dock-and-lock method for improved cancer imaging and therapy by pretargeting. J Nucl Med. 2008;49(1):158-63.

27. Kontermann RE. Strategies for extended serum half-life of protein therapeutics. Curr Opin Biotechnol. 2011;22(6):868-76.

28. Fishburn CS. The pharmacology of PEGylation: balancing PD with PK to generate novel therapeutics. J Pharm Sci. 2008;97(10):4167-83.

29. Merlot AM, Kalinowski DS, Kovacevic Z, Jansson PJ, Lane DJ, Huang ML-H, et al. Making a case for albumin - a highly promising drug-delivery system. Future Med Chem. 2015;7(5):553-6.

30. Fan D, Li Z, Zhang X, Yang Y, Yuan X, Zhang $X$, et al. AntiCD3Fv fused to human interleukin-3 deletion variant redirected $T$ cells against human acute myeloid leukemic stem cells. J Hematol Oncol. 2015:8(1):18.

31. Satta A, Mezzanzanica D, Turatti F, Canevari S, Figini M. Redirection of T-cell effector functions for cancer therapy: bispecific antibodies and chimeric antigen receptors. Future Oncol. 2013;9(4):527-39.

32. Zugmaier $G$, Klinger $M$, Schmidt $M$, Subklewe $M$. Clinical overview of antiCD19 BiTE $^{\circledast}$ and ex vivo data from anti-CD33 BiTE ${ }^{\circledast}$ as examples for retargeting $T$ cells in hematologic malignancies. Mol Immunol. 2015;67(2):58-66.

33. Lindhofer $\mathrm{H}$, Mocikat $\mathrm{R}$, Steipe $\mathrm{B}$, Thierfelder $\mathrm{S}$. Preferential species-restricted heavy/light chain pairing in rat/mouse quadromas. Implications for a singlestep purification of bispecific antibodies. J Immunol. 1995;155(1):219-25.

34. Hirschhaeuser F, Leidig T, Rodday B, Lindemann C, Mueller-Klieser W. Test system for trifunctional antibodies in 3D MCTS culture. J Biomol Screen. 2009:14(8):980-90.

35. Weidle UH, Kontermann RE, Brinkmann U. Tumor-antigen-binding bispecific antibodies for cancer treatment. Semin Oncol. 2014:41(5):653-60.

36. Jäger $M$, Schoberth $A$, Ruf $P$, Hess J, Lindhofer $H$. The trifunctional antibody ertumaxomab destroys tumor cells that express low levels of human epidermal growth factor receptor 2. Cancer Res. 2009;69(10):4270-6.

37. Kiewe $P$, Hasmüller $S$, Kahlert $S$, Heinrigs M, Rack B, Marmé A, et al. Phase trial of the trifunctional anti-HER2 $x$ anti-CD3 antibody ertumaxomab in metastatic breast cancer. Clin Cancer Res Off J Am Assoc Cancer Res. 2006;12(10):3085-91.

38. Stanglmaier $M$, Faltin $M$, Ruf $P$, Bodenhausen $A$, Schröder $P$, Lindhofer $H$. Bi20 (fBTA05), a novel trifunctional bispecific antibody (anti-CD20 $\times$ antiCD3), mediates efficient killing of B-cell lymphoma cells even with very low CD20 expression levels. Int J Cancer. 2008:123(5):1181-9.

39. Breton CS, Nahimana A, Aubry D, Macoin J, Moretti P, Bertschinger M, et al. A novel anti-CD19 monoclonal antibody (GBR 401) with high killing activity against B cell malignancies. J Hematol Oncol. 2014;7(1):33.

40. Mullard A. FDA approves first bispecific. Nat Rev Drug Discov. 2014;14(1):7

41. Nagorsen D, Kufer P, Baeuerle PA, Bargou R. Blinatumomab: a historical perspective. Pharmacol Ther. 2012;136(3):334-42.

42. Wu J, Fu J, Zhang M, Liu D. Blinatumomab: a bispecific T cell engager (BiTE) antibody against CD19/CD3 for refractory acute lymphoid leukemia. J Hematol Oncol. 2015;8(1):111

43. Köhnke T, Krupka C, Tischer J, Knösel T, Subklewe M. Increase of PD-L1 expressing B-precursor ALL cells in a patient resistant to the CD19/CD3- 
bispecific $T$ cell engager antibody blinatumomab. J Hematol Oncol. 2015;8(1):111.

44. Tang J, Shen D, Zhang J, Ligler FS, Cheng K. Bispecific antibodies, nanoparticles and cells: bringing the right cells to get the job done. Expert Opin Biol Ther. 2015;15(9):1251-5.

45. Rader C. DARTs take aim at BiTEs. Blood. 2011;117(17):4403-4.

46. Uy G, Stewart S, Baughman J, Rettig M, Chichili G, Bonvini E, et al. A phase I trial of MGD006 in patients with relapsed acute myeloid leukemia (AML). J Immunother Cancer. 2014;2 Suppl 3:87.

47. Moore PA, Alderson R, Shah K, Yang Y, Burke S, Li H, et al. Abstract 669: development of MGD007, a gpA33 x CD3 bi-specific DART for T-cell immunotherapy of metastatic colorectal cancer. Cancer Res. 2014;74 Suppl 19:669.

48. Kipriyanov SM, Moldenhauer G, Schuhmacher J, Cochlovius B, Von der Lieth C-W, Matys ER, et al. Bispecific tandem diabody for tumor therapy with improved antigen binding and pharmacokinetics. J Mol Biol. 1999:293(1):41-56.

49. Wu J, Fu J, Zhang M, Liu D. AFM13: a first-in-class tetravalent bispecific anti-CD30/CD16A antibody for NK cell-mediated immunotherapy. J Hematol Oncol. 2015;8(1):96.

50. Gschwind A, Fischer OM, Ullrich A. The discovery of receptor tyrosine kinases: targets for cancer therapy. Nat Rev Cancer. 2004;4(5):361-70.

51. McDonagh CF, Huhalov A, Harms BD, Adams S, Paragas V, Oyama S, et al. Antitumor activity of a novel bispecific antibody that targets the ErbB2/ ErbB3 Oncogenic unit and inhibits Heregulin-induced activation of ErbB3. Mol Cancer Ther. 2012;11(3):582-93.

52. Fitzgerald JB, Johnson BW, Baum J, Adams S, ladevaia S, Tang J, et al. MM141, an IGF-IR- and ErbB3-directed bispecific antibody, overcomes network adaptations that limit activity of IGF-IR inhibitors. Mol Cancer Ther. 2014;13(2):410-25.

53. Cole P. Duligotuzumab. Human anti-EGFR/anti-HER3 MAb, colorectal cancer therapy, head and neck cancer therapy. Drugs Future. 2015;40(3):167.

54. Fayette J, Wirth LJ, Oprean C, Hitt R, Udrea A, Jimeno A, et al. Randomized phase II study of Mehd7945a (mehd) vs cetuximab (cet) in >= 2nd-line recurrent/metastatic squamous cell carcinoma of the head \& neck (rmscchn) progressive on/after platinum-based chemotherapy (ptct). Ann Oncol. 2014;25 suppl 4:iv340.

55. Clement PM, Machiels JP, Wirth L, Specenier P, Seiwert T, Mardjuadi F, et al. 989pdphase 1b study of MEHD7945A (mehd) Plus Cisplatin/Fluorouracil (cis/5fu) or Carboplatin/Paclitaxel (carbo/Pac) for 1st-Line Treatment of Recurrent/Metastatic Squamous Cell Carcinoma of Head and Neck (rmscchn). Ann Oncol. 2014;25(suppl 4):iv341-iv341.

56. Ruoslahti E. Specialization of tumour vasculature. Nat Rev Cancer. 2002;2(2):83-90.

57. Biel NM, Siemann DW. Targeting the angiopoietin-2/Tie-2 axis in conjunction with VEGF signal interference. Cancer Lett. doi:10.1016/j.canlet. 2014.09.035

58. Siebert S, Tsoukas A, Robertson J, Mclnnes I. Cytokines as therapeutic targets in rheumatoid arthritis and other inflammatory diseases. Pharmacol Rev. 2015;67(2):280-309.

59. Schett G, Elewaut D, Mclnnes IB, Dayer J-M, Neurath MF. How cytokine networks fuel inflammation: toward a cytokine-based disease taxonomy. Nat Med. 2013;19(7):822-4.

60. Yao X, Huang J, Zhong H, Shen N, Faggioni R, Fung M, et al. Targeting interleukin-6 in inflammatory autoimmune diseases and cancers. Pharmacol Ther. 2014;141(5):125-39.

61. Baeten DLP, Kuchroo VK. How cytokine networks fuel inflammation: interleukin-17 and a tale of two autoimmune diseases. Nat Med. 2013;19(7):824-5.

62. Banchereau J, Pascual V, O'Garra A. From IL-2 to IL-37: the expanding spectrum of anti-inflammatory cytokines. Nat Immunol. 2012;13(10):925-31.

63. Bossaller $\mathrm{L}$, Rothe $\mathrm{A}$. Monoclonal antibody treatments for rheumatoid arthritis. Expert Opin Biol Ther. 2013;13(9):1257-72.

64. Williams SC. Small nanobody drugs win big backing from pharma. Nat Med. 2013;19(11):1355-6.

65. Nuñez-Prado N, Compte M, Harwood S, Álvarez-Méndez A, Lykkemark S, Sanz $L$, et al. The coming of age of engineered multivalent antibodies. Drug Discov Today. 2015;20(5):588-94.

66. Ekerljung L, Bass T, Wållberg H, Sohrabian A, Anderson K, Friedman M, et al. Bispecific affibody molecules for targeting of EGFR and HER2. mAbs. 2012; 4(1):14-6.
67. Kingwell K. InterMune and Boehringer blaze trails for idiopathic pulmonary fibrosis drugs. Nat Rev Drug Discov. 2014;13(7):483-4.

68. McBride WJ, Sharkey RM, Karacay H, D'Souza CA, Rossi EA, Laverman P, et al. A novel method of 18F radiolabeling for PET. J Nucl Med. 2009;50(6):991-8.

69. Metz S, Haas AK, Daub K, Croasdale R, Stracke J, Lau W, et al. Bispecific digoxigenin-binding antibodies for targeted payload delivery. Proc Natl Acad Sci. 2011;108(20):8194-9.

70. Taylor K. Engineering bispecific antibodies for targeted delivery of cytotoxin-loaded nanoparticles to tumour cells. The Australian Institute for Bioengineering and Nanotechnology, University of Queensland. 2015. doi: 10.14264/uql.2015.802

71. Schoffelen R, Boerman O, Van Der GW, Van HC, Sharkey R, McBride W, et al. Phase I clinical study of the feasibility of pretargeted radioimmunotherapy (PT-RAIT) in patients with colorectal cancer (CRC): first results. J Nucl Med. 2011:52 suppl 1:358.

72. Stanimirovic D, Kemmerich $K$, Haqqani AS, Farrington GK: Engineering and pharmacology of blood-brain barrier-permeable bispecific antibodies. Adv Pharmacol. 2014;71:301-335.

73. Couch JA, Yu YJ, Zhang Y, Tarrant JM, Fuji RN, Meilandt WJ, et al. Addressing safety liabilities of TfR bispecific antibodies that cross the bloodbrain barrier. Sci Transl Med. 2013;5(183):183ra57.

74. Atwal JK, Chen Y, Chiu C, Mortensen DL, Meilandt WJ, Liu Y, et al. A therapeutic antibody targeting BACE1 inhibits amyloid- $\beta$ production in vivo. Sci Transl Med. 2011;3(84):84ra43.

75. Hannah Byrne PJC. A tale of two specificities: bispecific antibodies for therapeutic and diagnostic applications. Trends Biotechnol. 2013;31:11.

76. Milstein C, Cuello AC. Hybrid hybridomas and their use in immunohistochemistry. Nature. 1983;305(5934):537-40.

77. Suresh MR, Cuello AC, Milstein C. Advantages of bispecific hybridomas in one-step immunocytochemistry and immunoassays. Proc Natl Acad Sci. 1986;83(20):7989-93.

78. DiGiandomenico A, Keller AE, Gao C, Rainey GJ, Warrener P, Camara MM, et al. A multifunctional bispecific antibody protects against pseudomonas aeruginosa. Sci Transl Med. 2014;6(262):262ra155.

79. Kingwell K. Infectious diseases: two-hit antibody tackles bacteria. Nat Rev Drug Discov. 2015;14(1):15.

80. Berg J, Lötscher E, Steimer KS, Capon DJ, Baenziger J, Jäck HM, et al. Bispecific antibodies that mediate killing of cells infected with human immunodeficiency virus of any strain. Proc Natl Acad Sci. 1991;88(11):4723-7.

81. Park SS, Ryu CJ, Kang YJ, Kashmiri SVS, Hong HJ. Generation and characterization of a novel tetravalent bispecific antibody that binds to hepatitis B virus surface antigens. Mol Immunol. 2000;37(18):1123-30.

82. Taylor RP, Martin EN, Reinagel ML, Nardin A, Craig M, Choice Q, et al. Bispecific monoclonal antibody complexes facilitate erythrocyte binding and liver clearance of a prototype particulate pathogen in a monkey model. J Immunol. 1997;159(8):4035-44.

83. Fan D, Li W, Yang Y, Zhang X, Zhang Q, Yan Y, et al. Redirection of CD4+ and CD8+ T lymphocytes via an anti-CD3 $\times$ anti-CD19 bi-specific antibody combined with cytosine arabinoside and the efficient lysis of patientderived B-ALL cells. J Hematol Oncol. 2015;8(1):108.

\section{Submit your next manuscript to BioMed Central and we will help you at every step:}

- We accept pre-submission inquiries

- Our selector tool helps you to find the most relevant journal

- We provide round the clock customer support

- Convenient online submission

- Thorough peer review

- Inclusion in PubMed and all major indexing services

- Maximum visibility for your research

Submit your manuscript at www.biomedcentral.com/submit 